\title{
Binding, Internalization, and Degradation of Mannose-terminated Glucocerebrosidase by Macrophages
}

\author{
Yutaka Sato and Ernest Beutler \\ Department of Molecular and Experimental Medicine, The Scripps Research Institute, La Jolla, California 92037
}

\begin{abstract}
Mannose-terminated glucocerebrosidase (alglucerase; Ceredase $\left.^{\circledR}\right)$ was designed for enzyme replacement therapy in Gaucher disease to take advantage of mannose receptor-mediated endocytosis by macrophages. To provide a rational basis for designing enzyme replacement therapy protocols, we examined the in vitro binding, uptake, and degradation of alglucerase by murine and human macrophages. Both were found to have $\sim$ 500,000 mannose-dependent receptors for alglucerase per cell with a $K_{d}$ of $10^{-7} \mathrm{M}$ at $0^{\circ} \mathrm{C}$. In contrast, the number of binding sites for mannose-bovine serum albumin (mannoseBSA), the classical ligand for the mannose receptor, was only $\sim 20,000$ with a $K_{d}$ of $10^{-8} \mathrm{M}$. Alglucerase was also bound in a mannose-dependent manner by cells that lack the capacity to bind mannose-BSA, such as Cos-1 cells, endothelial cells, and peripheral blood monocytes. The fact that the binding of alglucerase by macrophages was mediated principally by a receptor distinct from the classical mannose receptor that binds mannose-BSA was confirmed by differential inhibitors, viz., $\alpha$ methyl-glucoside, fucose, and mannose-BSA, and by its independence on $\mathrm{Ca}^{2+}$.

Uptake of alglucerase by macrophages at $37^{\circ} \mathrm{C}$ was concentration dependent and half maximal at $10^{-6} \mathrm{M}$. However, at a concentration of $10^{-7} \mathrm{M}$, only $0.5 \%$ of the added alglucerase was incorporated into macrophages and $\sim 50 \%$ of the alglucerase taken up was quickly released into the medium. Endothelial cells also manifest mannose-dependent binding and uptake of alglucerase and may therefore account for a large proportion of the infused alglucerase. Our data suggest that only a small amount of the alglucerase administered is effectively delivered to macrophages and that a more efficiently targeted enzyme might have a marked therapeutic advantage over mannose-terminated glucocerebrosidase. (J. Clin. Invest. 1993. 91:19091917.) Key words: Gaucher disease • enzyme replacement therapy $\bullet$ receptor-mediated endocytosis • alglucerase $\bullet$ mannose receptor
\end{abstract}

\section{Introduction}

Gaucher disease is an autosomal recessive disorder caused by a deficiency of glucocerebrosidase, the enzyme required for the lysosomal degradation of the sphingoglycolipid glucocerebro-

Address correspondence to Ernest Beutler, Department of Molecular and Experimental Medicine, The Scripps Research Institute, 10666 North Torrey Pines Road, La Jolla, CA 92037.

Received for publication 23 July 1992 and in revised form 7 December 1992.

J. Clin. Invest.

(c) The American Society for Clinical Investigation, Inc. $0021-9738 / 93 / 05 / 1909 / 09 \$ 2.00$

Volume 91, May 1993, 1909-1917 side (1). In its absence the insoluble glucocerebroside accumulates in macrophages. Because reticuloendothelial cells by their very nature should take up exogenously administered material, this disorder seemed particularly well suited to enzyme replacement therapy. Although a number of attempts to treat the disorder with exogenously administered enzyme were made in the 1970 s, the results were disappointing (2-6). With the discovery of mannose receptors on macrophages and their role in endocytosis $(7)$, it was suggested $(8,9)$ that incorporating a mannose signal into native enzyme might be useful for enzyme targeting in Gaucher disease. Although $\sim 20 \%$ of the total oligosaccharides on the native glucocerebrosidase are high mannose type (10), sequential deglycosylation to produce a mannose-terminated enzyme to improve the efficacy of targeting was proposed (11). Ultimately, this modified enzyme became available commercially as a licensed treatment for Gaucher disease (alglucerase; Ceredase $^{\circledR}$ ). Although several groups have reported promising clinical results using alglucerase (12-14), the optimal dose and frequency of administration of alglucerase are controversial (15-17).

The design of optimal protocols for enzyme replacement therapy requires understanding of the kinetics of alglucerase targeting. In this report, we examine the binding, uptake, and degradation of alglucerase by murine and human macrophages in vitro.

\section{Methods}

Reagents. Unless otherwise specified, all chemicals were obtained from Sigma Chemical Co. (St. Louis, MO). RPMI 1640 medium, DMEM, and FCS were purchased from Whittaker Bioproducts (Walkersville, MD). Medium 199 and pooled human type AB serum were purchased from Gibco BRL Life Technologies, Inc. (Grand Island, NY). Mannose-BSA ( $35 \mathrm{~mol}$ saccharide/mol BSA) was purchased from E-Y Laboratories, Inc. (San Mateo, CA). PBS contained the following $(\mathrm{mM}): 138 \mathrm{NaCl}, 2.7 \mathrm{KCl}, 1.2 \mathrm{KH}_{2} \mathrm{PO}_{4}, 8.1 \mathrm{Na}_{2} \mathrm{HPO}_{4} \cdot 7 \mathrm{H}_{2} \mathrm{O}$.

Alglucerase from Ceredase ${ }^{\star}$. Residual Ceredase ${ }^{\otimes}$ (Genzyme Corp., Cambridge, MA) was collected from used vials. The $1 \%$ human albumin added to alglucerase as a stabilizer in Ceredase ${ }^{\circledR}$ was removed by taking advantage of the binding of glucocerebrosidase to concanavalin A-Sepharose (Sigma Chemical Co.) (18). $2 \mathrm{ml}$ of diluted Ceredase ${ }^{\circledR}$ was applied to a column $(0.7 \times 2.5 \mathrm{~cm})$ equilibrated with buffer $\mathrm{A}(50$ $\mathrm{mM}$ citrate $/ \mathrm{NaOH}, 50 \mathrm{mM} \mathrm{NaCl}, 0.5 \%$ taurocholic acid, $\mathrm{pH} 6.0$ ). The column was washed with $15 \mathrm{ml}$ of buffer A followed by elution with 50 $\mathrm{ml}$ of buffer A containing $0.2 \mathrm{M}$ methyl- $\alpha$-mannopyranoside. The eluate was concentrated using PM30 (Amicon, Beverly, MA) and dialyzed against PBS overnight. This alglucerase preparation was determined to be pure by use of SDS-PAGE with a specific activity of 50 $\mathrm{U} / \mathrm{mg}$ protein and on SDS-PAGE a subunit molecular weight of 59,300 .

Iodination of alglucerase and mannose-BSA. $100 \mu \mathrm{g}$ of protein was incubated with $0.5 \mathrm{mCi}$ of $\mathrm{Na}^{125} \mathrm{I}$ (Amersham Corp., Arlington Heights, IL) and $10 \mu \mathrm{g}$ of Iodo-Gen (Pharmacia LKB Biotechnology Inc., Piscataway, $\mathrm{NJ}$ ) immobilized in a polystyrene tube for $10 \mathrm{~min}$. The reaction was terminated by gel filtration on a PD-10 column 
(Pharmacia LKB Biotechnology Inc.). Protein determination was performed by the Lowry et al. method (19). Specific radioactivity was typically $2-3 \times 10^{6} \mathrm{cpm} / \mu \mathrm{g}$ for alglucerase and $5-6 \times 10^{6} \mathrm{cpm} / \mu \mathrm{g}$ for mannose-BSA and, on average, $94 \%$ of total counts were TCA precipitable.

Murine peritoneal macrophages. Peritoneal macrophages were obtained by irrigating the peritoneal cavity of 6-8-wk-old female BALB/ CBYJ mice with medium (medium 199 plus $10 \%$ FCS). Cells were washed, resuspended in the same medium, and seeded into 24-well plates (Corning Glass Inc., Corning, NY) at $5 \times 10^{5}$ cells per well. Adherent cell monolayers were prepared after a 4 -h incubation at $37^{\circ} \mathrm{C}$ in the presence of $5 \% \mathrm{CO}_{2}$ by washing unattached cells from the plate with assay medium. Adherent cell monolayers at this stage will be referred to as murine macrophages and were used in various assays.

Human monocyte-derived macrophages. Mononuclear cells were separated from $50 \mathrm{ml}$ of EDTA-anticoagulated blood from healthy volunteers by Ficoll-Hypaque centrifugation. The cells were washed three times in PBS containing $0.53 \mathrm{mM}$ EDTA and resuspended in RPMI 1640 with $10 \%$ FCS. Monocytes were isolated by using gelatin/ plasma-coated flasks as reported previously (20). More than $90 \%$ of the adherent cells were shown to be monocytes by Wright-Giemsa staining. The monocytes were resuspended in RPMI 1640 supplemented with $4 \mathrm{mM}$ glutamine, $2 \%$ PenStrep, and $5 \%$ pooled human type $\mathrm{AB}$ serum and seeded into 24 -well plates at $4 \times 10^{5}$ cells per well and cultured at $37^{\circ} \mathrm{C}$ under $5 \% \mathrm{CO}_{2}$ for $7 \mathrm{~d}$.

Umbilical cord-derived endothelial cells. These cells were a kind gift from Dr. E. Levin (The Scripps Research Institute).

Uptake and binding assays. Assays for uptake and binding in adherent cells were done according to the method previously described with some modifications (21). The medium was removed and cells were washed twice with HHBG (HBSS, $10 \mathrm{mM}$ Hepes, $10 \mathrm{mM} N$-tris(hydroxymethyl)methyl-2-aminoethane-sulfonic acid, $0.1 \%$ glucose, and $1 \%$ BSA ). Labeled alglucerase with or without mannan $(3 \mathrm{mg} / \mathrm{ml})$ in HHBG was added in a final volume of $0.4 \mathrm{ml}$. After incubation, the medium was removed and an aliquot was precipitated with $10 \%$ TCA to determine acid-soluble counts. The cell layer was washed four times with $\mathrm{HBSS}$, and then solubilized in $0.5 \mathrm{ml}$ of $1.0 \mathrm{~N} \mathrm{NaOH}$ for determination of cell-associated radioactivity. Assays were conducted at $0^{\circ} \mathrm{C}$ (binding) or $37^{\circ} \mathrm{C}$ (uptake). Binding and uptake in the presence of mannan is designated as mannose independent. The difference between binding or uptake with or without mannan is designated as mannose dependent. Murine peritoneal macrophages were enumerated in a hemocytometer after $5 \mathrm{~min}$ of incubation in $0.005 \%$ Zwittergent (Calbiochem, San Diego, CA) (22). As it is difficult to detach human monocyte-derived macrophages with intact shape in $0.005 \%$ Zwittergent, cells were dissolved in $0.1 \%$ Triton X-100 and their nuclei were enumerated. Endothelial cells were detached in trypsin-EDTA solution (Whittaker Bioproducts).

Transfection of the mannose receptor full-length cDNA into Cos-1 cells. Cos-1 cells were maintained in DME supplemented with $4 \mathrm{mM}$ glutamine, $2 \%$ PenStrep, and $10 \% \mathrm{FCS}$ at $37^{\circ} \mathrm{C}$ under $5 \% \mathrm{CO}_{2}$.

Mannose receptor full-length cDNA in expression vector pCDM8 was a kind gift from Dr. A. Ezekowitz (Children's Hospital, Dana Farber Cancer Institute, Boston, MA). Cos-1 cells were transfected using the DEAE-dextran method as previously reported (23). Transfected Cos-1 cells were trypsinized $24 \mathrm{~h}$ after transfection and replated in 24-well plates and cultivated for a further $2 \mathrm{~d}$ in culture medium. Mock-transfected Cos-1 cells served as controls.

Assay for glucocerebrosidase activity. Enzyme activity was measured using 4-methyl umbelliferyl- $\beta$-glucoside as substrate (24).

\section{Results}

Competition of unlabeled with labeled alglucerase. Fig. 1 shows mannose-dependent binding by murine macrophages. Cells were incubated with different ratios of unlabeled to ${ }^{125} \mathrm{I}$-labeled alglucerase, maintaining the same total concentration, a level at which mannose-dependent binding is almost saturated. The

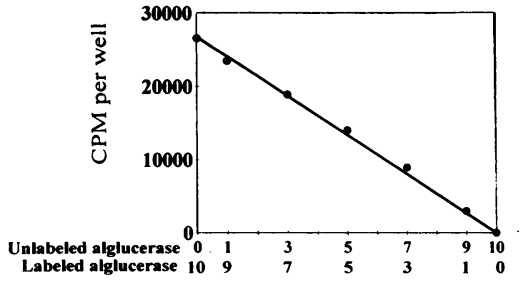

Figure 1. Competition of unlabeled with labeled alglucerase for binding. Murine peritoneal macrophages were incubated with several different ratios of unlabeled to labeled alglucerase, maintaining the total concentration at $30 \mu \mathrm{g} / \mathrm{ml}\left(5 \times 10^{-7} \mathrm{M}\right)$ for $180 \mathrm{~min}$ at $0^{\circ} \mathrm{C}$. Mannose-dependent cell-associated radioactivity was assayed as described in Methods. Results are the mean of duplicate assays and are representative of two independent experiments.

product of alglucerase concentration and radioactivity remained constant, indicating that the ${ }^{125} \mathrm{I}$-labeled alglucerase has the same binding properties as the unlabeled alglucerase.

Binding and uptake of alglucerase by murine peritoneal macrophages. The time course of mannose-dependent binding at $0^{\circ} \mathrm{C}$ showed that it reached equilibrium after $120 \mathrm{~min}$ (Fig. 2 ). Using 180-min incubations, we examined the concentration dependence of alglucerase binding (Fig. $3 \mathrm{~A}$ ). Analysis of mannose-dependent binding by the Scatchard method provided an estimate of $4.5 \times 10^{5}$ receptors per cell with $K_{\mathrm{d}}=1.2$ $\times 10^{-7} \mathrm{M}$ (Fig. $3 \mathrm{~B}$ ). Scatchard analysis of mannose-independent binding shows there are two major classes of binding sites, a small number of sites with high affinity $\left(0.5 \times 10^{5}\right.$ sites per cell, $\left.K_{\mathrm{d}}=9.8 \times 10^{-9} \mathrm{M}\right)$ and a number of sites too large to measure accurately with low affinity (Fig. $3 C$ ). Studies in the presence of both mannan and galactose showed lack of the high affinity binding, suggesting that this binding site with high affinity might be a galactose receptor (Fig. $3 \mathrm{D}$ ).

Uptake of alglucerase at $37^{\circ} \mathrm{C}$ was approximately linear for $\geq 60$ min (Fig. 4). We examined the TCA precipitability of media at each point, but there was little increase of TCA-soluble materials, indicating that within $60 \mathrm{~min}$ little degradation of alglucerase occurs (data not shown). Concentration dependence of alglucerase uptake after $20 \mathrm{~min}$ of incubation (Fig. 5) indicates that uptake exceeds binding by an order of magnitude and does not saturate even at $80 \mu \mathrm{g} / \mathrm{ml}\left(1.3 \times 10^{-6} \mathrm{M}\right)$. A double reciprocal plot indicates that one-half maximal uptake is achieved at $9.6 \times 10^{-7} \mathrm{M}$.

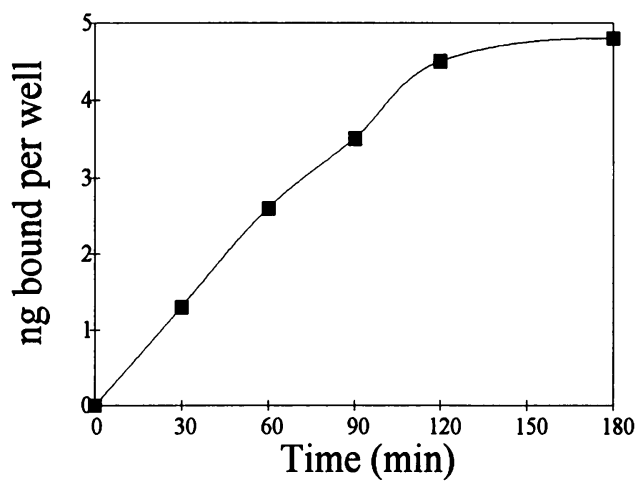

Figure 2. Binding of alglucerase to murine peritoneal macrophages as a function of time. Murine peritoneal macrophages were incubated with $10 \mu \mathrm{g} / \mathrm{ml}\left(1.7 \times 10^{-7} \mathrm{M}\right)$ of labeled alglucerase at $0^{\circ} \mathrm{C}$. At the time indicated, mannose-dependent binding was assayed as described in Methods. Results are the mean of duplicate assays and are representative of two independent experiments. 

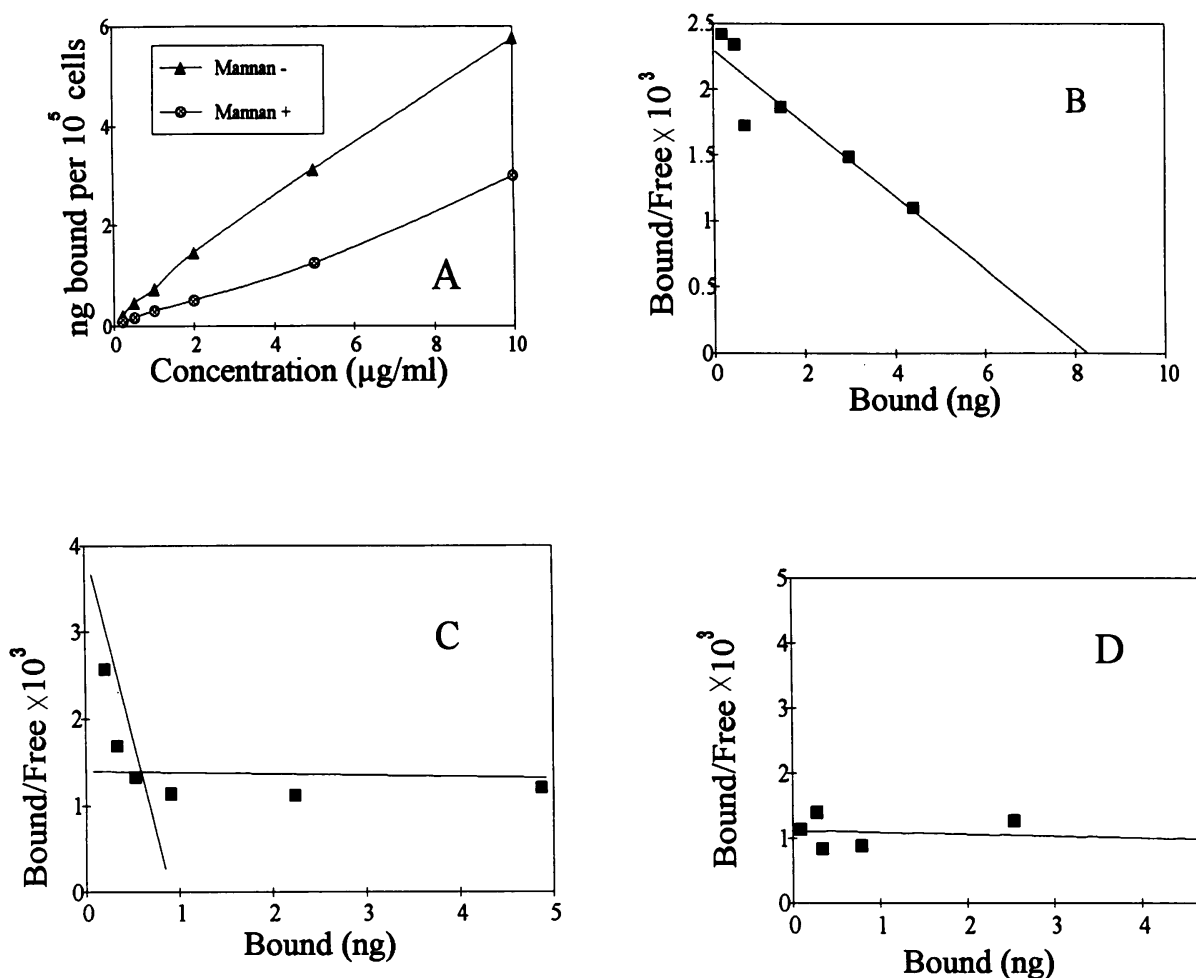

Degradation of the internalized alglucerase in murine peritoneal macrophages. Cells were incubated with labeled alglucerase at $37^{\circ} \mathrm{C}$ for $60 \mathrm{~min}$, after which they were washed free of excess labeled alglucerase, resuspended in prewarmed medium, and further incubated at $37^{\circ} \mathrm{C}$. The TCA-precipitable and -soluble radioactivity in the medium and the cell-associated radioactivity were measured at intervals. Cell-associated TCA-soluble radioactivity was negligible (data not shown). Fig. 6 shows that there was a rapid decrease of cell-associated radioactivity followed by a plateau. Two thirds of the radioactivity remained after $4 \mathrm{~h}$. Small but gradually increasing amounts of TCA-soluble materials were detected in the medium, indicating that proteolytic degradation of alglucerase occurs very slowly. Corresponding to the decrease in cell-asso-

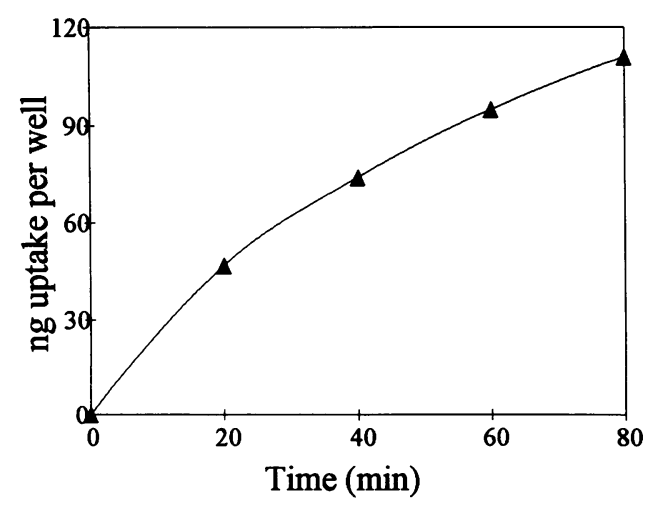

Figure 4. Uptake of alglucerase by murine peritoneal macrophages as a function of time. Murine peritoneal macrophages were incubated with $40 \mu \mathrm{g} / \mathrm{ml}\left(6.7 \times 10^{-7} \mathrm{M}\right)$ of labeled alglucerase at $37^{\circ} \mathrm{C}$. At the time indicated, mannose-dependent uptake was assayed as described in Methods. Results are the mean of duplicate assays and are representative of two independent experiments.
Bound (ng)
Figure 3. Binding of alglucerase to murine peritoneal macrophages as a function of concentration. $(A) \mathrm{Mu}$ rine peritoneal macrophages were incubated with various concentrations of labeled alglucerase in the presence or absence of mannan for $180 \mathrm{~min}$ at $0^{\circ} \mathrm{C}$. Binding was assayed as described in Methods. Results are the mean of duplicate assays and are representative of four independent experiments. $(B)$ Scatchard analysis of mannose-dependent binding. $(C)$ Scatchard analysis of mannose-independent binding in the presence of mannan. (D) Scatchard analysis of mannose-independent binding in the presence of both mannan and $50 \mathrm{mM}$ galactose. ciated radioactivity, there was a rapid increase in TCA-precipitable radioactivity in the medium. This radioactive material, when incubated with fresh cells at $0^{\circ} \mathrm{C}$, was bound, suggesting that it could represent intact alglucerase released from cells (data not shown). After the first hour, release of label from the cells reaches a plateau. This is not due to an equilibrium between uptake and release, since replacing the medium with fresh medium at $2 \mathrm{~h}$ had little effect on the amount of intracellular labeled alglucerase.

Binding and uptake of alglucerase by human monocytederived macrophages. Fig. $7 A$ shows the concentration dependence of binding in human monocyte-derived macrophages.

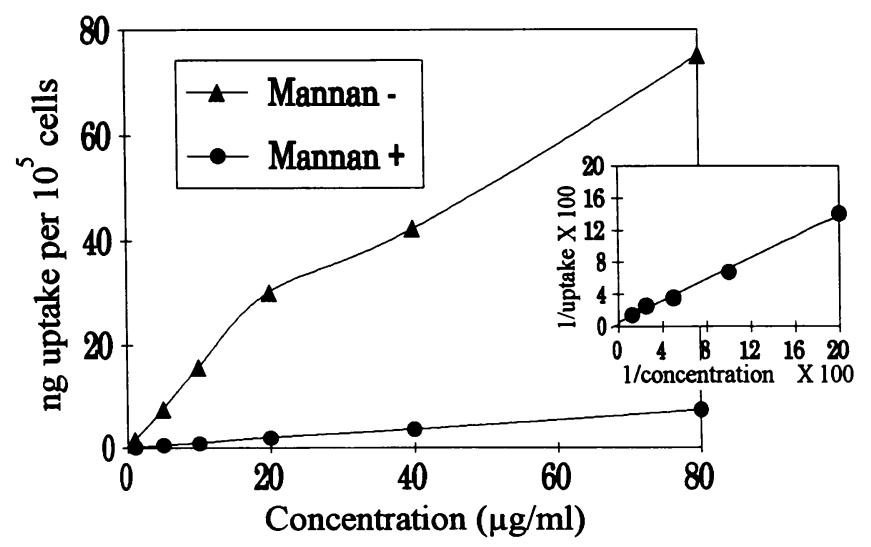

Figure 5. Uptake of alglucerase by murine peritoneal macrophages as a function of concentration. Murine peritoneal macrophages were incubated with various concentrations of labeled alglucerase in the presence or absence of mannan for $20 \mathrm{~min}$ at $37^{\circ} \mathrm{C}$. Uptake was assayed as described in Methods. Results are the mean of duplicate assays and are representative of four independent experiments. (Inset) A double reciprocal plot of mannose-dependent uptake. 


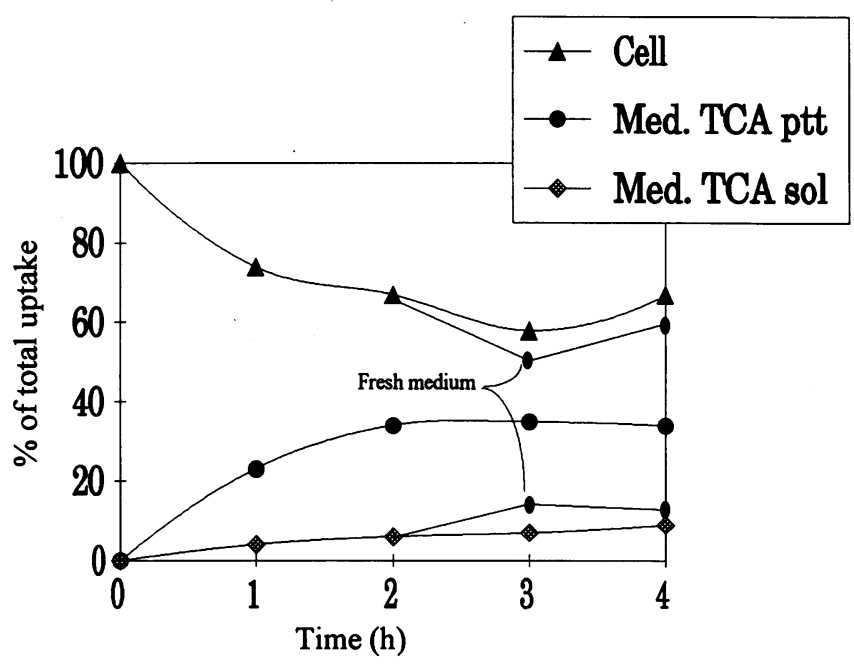

Figure 6. Fate of the internalized alglucerase in murine peritoneal macrophages. Murine peritoneal macrophages were incubated with $40 \mu \mathrm{g} / \mathrm{ml}\left(6.7 \times 10^{-7} \mathrm{M}\right)$ of labeled alglucerase for $60 \mathrm{~min}$ at $37^{\circ} \mathrm{C}$ followed by washing with Hank's solution at $0^{\circ} \mathrm{C}$. Cells were incubated in fresh medium without alglucerase at $37^{\circ} \mathrm{C}$. At the time indicated, the medium and the first wash were combined and precipitated with 10\% TCA to determine acid-soluble counts. Cell-associated radioactivity was determined as described in Methods. For one portion of the cells the medium was replaced with fresh medium at the 2-h point and further incubated at $37^{\circ} \mathrm{C}$. Radioactivity present in each fraction is expressed as percent of the total initial cell-associated radioactivity after incubation with labeled alglucerase. Results are the mean of duplicate assays and are representative of three independent experiments.

The Scatchard plot of mannose-dependent binding yielded a value of $6.3 \times 10^{5}$ receptors per cell, with a dissociation constant of $7.0 \times 10^{-8} \mathrm{M}$ (Fig. $7 \mathrm{~B}$ ). In contrast to murine peritoneal macrophages, mannose-independent binding sites with a high affinity constant were not observed but the number of low-affinity, mannose-independent sites were again too large to measure (Fig. $7 C$ ).

The mannose-dependent uptake was concentration dependent and, from a double reciprocal plot, the concentration giving one-half maximal uptake was determined to be $1.1 \times 10^{-6}$ M (Fig. 8). Compared with murine peritoneal macrophages, the percentage of mannose-independent uptake in total uptake was somewhat higher in human monocyte-derived macrophages.

Degradation of the internalized alglucerase in human monocyte-derived macrophages. Because mannose-independent uptake is high by human monocyte-derived macrophages, we examined separately the fate of alglucerase that was taken up both in the presence and the absence of mannan. As shown in Fig. 9, rapid release of intact labeled alglucerase into medium and concomitant decrease in cellular labeled alglucerase were observed just as in murine peritoneal macrophages. About half of the alglucerase that had been taken up in the presence of mannan remained intracellularly after $5 \mathrm{~h}$.

Uptake of alglucerase by monocyte-derived macrophages from a Gaucher disease patient. Using blood from a Gaucher disease patient, we prepared monocyte-derived macrophages and examined the uptake of unlabeled alglucerase by these cells by measuring cellular catalytic activity using 4-methyl umbelliferyl- $\beta$-glucoside as a substrate. The patient's monocyte-de-
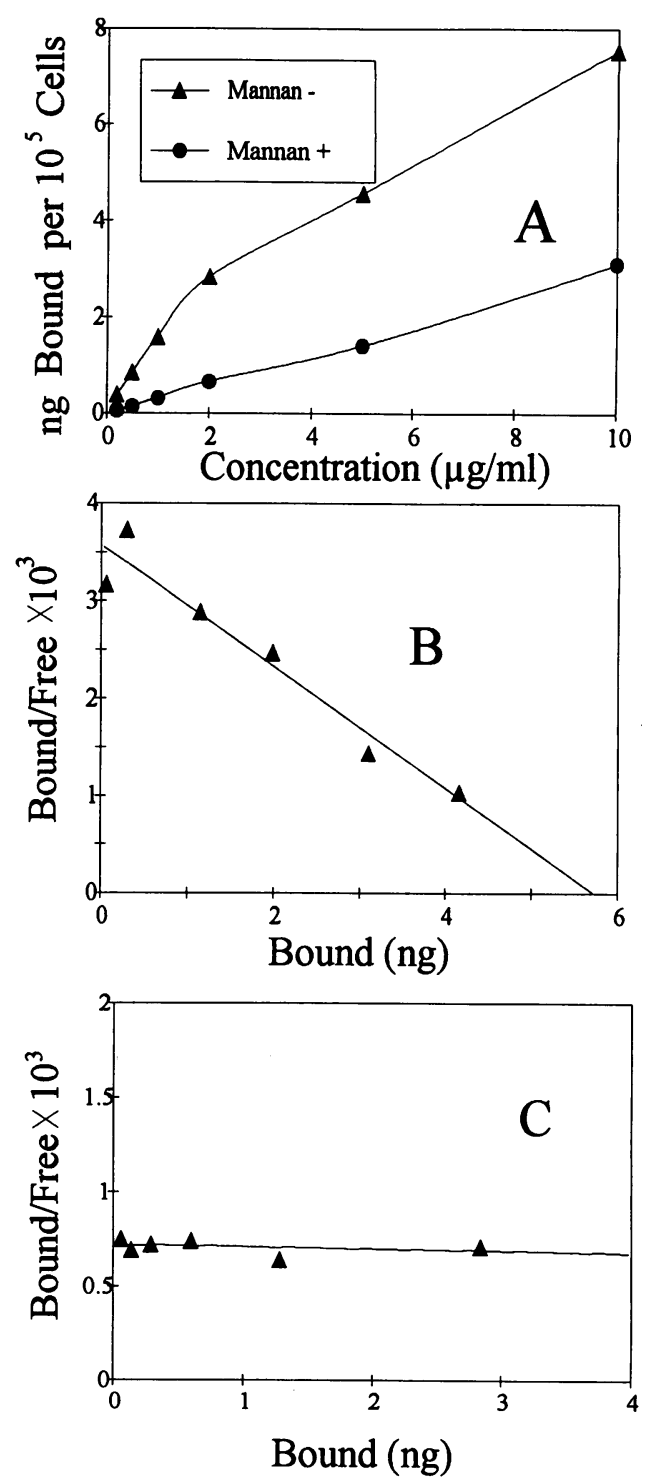

Figure 7. Binding of alglucerase to human monocyte-derived macrophages as a function of concentration. $(A)$ Cells were incubated with various concentrations of labeled alglucerase in the presence or absence of mannan for $180 \mathrm{~min}$ at $0^{\circ} \mathrm{C}$. Binding was assayed as described in Methods. Results are the mean of duplicate assays and are representative of four independent experiments. $(B)$ Scatchard analysis of mannose-dependent binding. $(C)$ Scatchard analysis of mannose-independent binding.

rived macrophages had $34 \mu \mathrm{U}$ per $10^{5}$ cells of endogenous catalytic activity, $\sim 10 \%$ that of normal cells $\left(300 \mu \mathrm{U}\right.$ per $10^{5}$ cells). After incubation with $5 \mu \mathrm{g} / \mathrm{ml}(250,000 \mu \mathrm{U} / \mathrm{ml}, 8.4$ $\times 10^{-8} \mathrm{M}$ ) of unlabeled alglucerase for $60 \mathrm{~min}$ at $37^{\circ} \mathrm{C}$, the patient's monocyte-derived macrophages contained $132 \mu \mathrm{U}$ per $10^{5}$ cells, with a mean uptake of $2.0 \mathrm{ng}$ (corresponding to $98 \mu \mathrm{U}$ ) per $10^{5}$ cells. At the same concentration using labeled alglucerase, we observed $2.7 \mathrm{ng}$ per $10^{5}$ cells of uptake.

Binding of alglucerase and mannose-BSA to Cos-1 cells and peripheral blood monocytes. We examined binding of alglucerase to monocytes and Cos-1 cells, each of which are reported to lack mannose receptor when mannose-BSA serves as the ligand $(23,25)$. Indeed, as Table I shows, we did not observe mannose-dependent binding of mannose-BSA to either of 


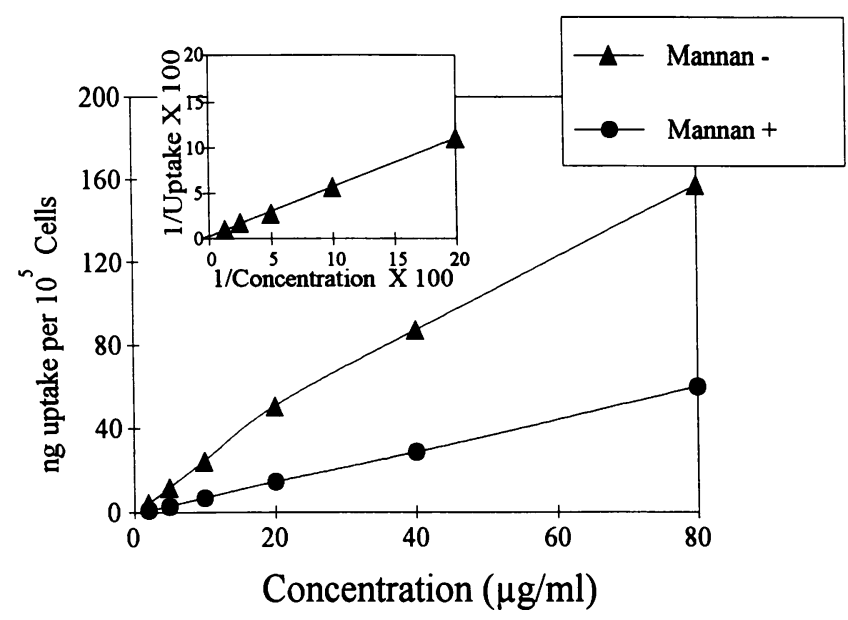

Figure 8. Uptake of alglucerase by human monocyte-derived macrophages as a function of concentration. Cells were incubated with various concentrations of labeled alglucerase in the presence or absence of mannan for $60 \mathrm{~min}$ at $37^{\circ} \mathrm{C}$. Uptake was assayed as described in Methods. Results are the mean of duplicate assays and are representative of four independent experiments. (Inset) A double reciprocal plot of mannose-dependent uptake.

these cell types; however, there was considerable mannose-dependent binding of alglucerase, suggesting that this enzyme can be bound to mannose-dependent receptor distinct from the classical mannose receptor that binds mannose-BSA.

Differential inhibition of mannose-dependent binding of alglucerase and mannose-BSA. We examined the inhibitory effects of various sugars on the binding of alglucerase to Cos- 1 cells and the binding of mannose-BSA to murine macrophages. As shown in Table II, several sugars exhibited similar inhibitory patterns on both systems, but $\alpha$ - and $\beta$-methyl-glucoside and fucose showed quite different inhibition on the binding of the two ligands. $\alpha$-methyl-glucoside strongly inhibited binding of alglucerase to Cos-1 cells but did not inhibit binding of mannose-BSA to macrophages. On the other hand, fucose inhibited binding of mannose-BSA to macrophages but did not inhibit binding of alglucerase to Cos- 1 cells.

The inhibitory effects of $\alpha$ - and $\beta$-methyl-glucoside and fucose on the binding of alglucerase to macrophages were similar to that on the binding of alglucerase to Cos-1 cells.

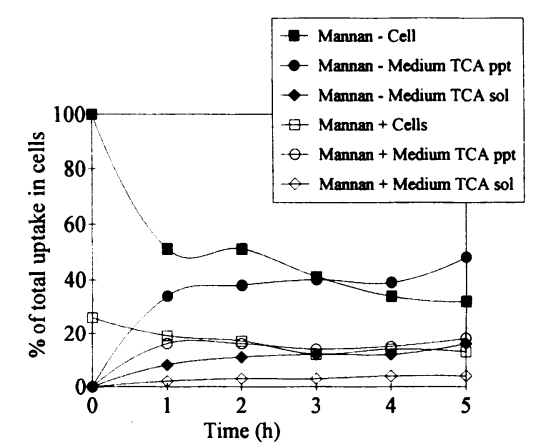

Figure 9. Fate of the internalized alglucerase in human monocyte-derived macrophages. Cells were incubated with $10 \mu \mathrm{g} / \mathrm{ml}(1.7$ $\left.\times 10^{-7} \mathrm{M}\right)$ of labeled alglucerase in the presence or absence of mannan for $60 \mathrm{~min}$ at $37^{\circ} \mathrm{C}$ followed by washing with Hanks' solution at $0^{\circ} \mathrm{C}$. Cells were further incubated in fresh medium without alglucerase at $37^{\circ} \mathrm{C}$. At the time indicated, medium and cells were treated as shown in Fig. 6. Radioactivity present in each fraction is expressed as percent of the total initial cell-associated radioactivity after incubation with labeled alglucerase. Results are the mean of duplicate assays and are representative of three independent experiments.
Table I. Binding of Alglucerase or Mannose-BSA to Cos-1 Cells and Monocytes

\begin{tabular}{lrr}
\hline & Alglucerase & Mannose-BSA \\
\hline & \multicolumn{2}{c}{ ng bound per well } \\
Cos-1 cells & & \\
Mannan (-) & $5.61 \pm 0.02$ & $0.15 \pm 0.005$ \\
Mannan (+) & $1.4 \pm 0.10$ & $0.15 \pm 0.005$ \\
Monocytes & & \\
Mannan (-) & $1.51 \pm 0.04$ & $0.038 \pm 0.003$ \\
Mannan (+) & $0.34 \pm 0.03$ & $0.039 \pm 0.003$ \\
\hline
\end{tabular}

Cos- 1 cells and monocytes were prepared as described in Methods. These cells were incubated with $5 \mu \mathrm{g} / \mathrm{ml}\left(8.4 \times 10^{-8} \mathrm{M}\right)$ of labeled alglucerase or $1 \mu \mathrm{g} / \mathrm{ml}\left(1.4 \times 10^{-8} \mathrm{M}\right)$ of labeled mannose-BSA in the presence or absence of mannan at $0^{\circ} \mathrm{C}$. Incubation times were 180 and 90 min for alglucerase and mannose-BSA, respectively. Binding was assayed as described in Methods. Results are the mean $\pm S D$ of triplicate assays and representative of two independent experiments.

$\mathrm{Ca}^{2+}$ dependency of mannose-dependent binding of alglucerase and mannose-BSA. To determine $\mathrm{Ca}^{2+}$ dependency of binding of ligand, we examined the effect of diethylenetriamineacetic acid (DTPA), ${ }^{1} \mathrm{a} \mathrm{Ca}^{2+}$ chelating agent. As shown in Table III, DTPA prevented mannose-dependent binding of mannose-BSA to macrophages but did not affect binding of alglucerase to Cos-1 cells or macrophages.

Contribution of the classical mannose receptor to binding of alglucerase to macrophages. The inhibitory effect of mannoseBSA on the binding of alglucerase to murine macrophages was measured to determine to what extent these two ligands compete for a common receptor. A two-component inhibitory curve was documented (Fig. 10). At concentrations $<40 \mu \mathrm{g} /$ $\mathrm{ml}\left(5.5 \times 10^{-7} \mathrm{M}\right)$, mannose-BSA strongly inhibited binding of alglucerase, but after $\sim 10 \%$ of the alglucerase binding had been inhibited, inhibition became much weaker.

Binding and uptake of alglucerase by Cos-1 cells transfected with the mannose receptor full-length $c D N A$. To determine the relative contribution of the classical mannose receptor and $\mathrm{Ca}^{2+}$-independent receptor for binding and uptake of alglucerase, we examined binding and uptake of alglucerase by control and mannose receptor cDNA-transfected Cos-1 cells. Cos-1 cells have been shown to lack the classical mannose receptor for mannose-BSA and gain the ability to bind this ligand after being transfected with mannose receptor cDNA (23). We confirmed that these cells acquired the capacity to bind and take up mannose-BSA in a mannose-dependent manner (Fig. 11). Although there is no increase of mannose-dependent binding of alglucerase in transfected cells compared with control cells, the uptake of alglucerase by transfected cells was greater, but not significantly so.

Binding and uptake of alglucerase by endothelial cells. As endothelial cells line blood vessels, alglucerase uptake by these cells must be considered in determining the in vivo fate of alglucerase. We therefore examined the kinetics of binding and uptake in umbilical cord-derived endothelial cells. Although

1. Abbreviation used in this paper: DTPA, diethylenetriamineacetic acid. 
Table II. Effects of Possible Inhibitors on the binding of Alglucerase and Mannose-BSA

\begin{tabular}{|c|c|c|c|c|}
\hline \multirow[b]{2}{*}{ Compound added } & \multicolumn{2}{|c|}{ Alglucerase to } & \multicolumn{2}{|c|}{ Mannose-BSA to } \\
\hline & Cos-1 & Macrophages & Cos-1 & Macrophages \\
\hline & \multicolumn{4}{|c|}{$\%$} \\
\hline None (control) & 100 & 100 & 100 & 100 \\
\hline Mannan $(3 \mathrm{mg} / \mathrm{ml})$ & 6 & 13 & 100 & 12 \\
\hline Methyl- $\alpha$-mannoside (50 mM) & 26 & 15 & - & 24 \\
\hline Galactose $(50 \mathrm{mM})$ & 92 & 74 & - & 87 \\
\hline Glucose (50 mM) & 28 & 46 & - & 46 \\
\hline Maltose (50 mM) & 23 & - & - & 27 \\
\hline$N$-acetyl-glucosamine (50 mM) & 40 & 42 & - & 26 \\
\hline$\alpha$-methyl-glucoside (10 mM) & 21 & 51 & - & 102 \\
\hline$\alpha$-methyl-glucoside (30 mM) & 15 & - & - & 95 \\
\hline$\alpha$-methyl-glucoside (50 mM) & 12 & - & - & 57 \\
\hline$\beta$-methyl-glucoside (10 mM) & 93 & 93 & - & 110 \\
\hline$\beta$-methyl-glucoside ( $30 \mathrm{mM})$ & 80 & - & - & 81 \\
\hline$\beta$-methyl-glucoside (50 mM) & 65 & - & - & 56 \\
\hline Fucose $(50 \mathrm{mM})$ & 91 & 88 & - & 25 \\
\hline Mannose-6-phosphate (50 mM) & 91 & 83 & - & - \\
\hline Dextran sulfate $(3 \mu \mathrm{g} / \mathrm{ml})$ & 121 & 122 & - & - \\
\hline
\end{tabular}

Cos- 1 cells or murine peritoneal macrophages were incubated with 5 $\mu \mathrm{g} / \mathrm{ml}\left(8.4 \times 10^{-8} \mathrm{M}\right)$ of labeled alglucerase or $1 \mu \mathrm{g} / \mathrm{ml}\left(1.4 \times 10^{-8}\right.$ $\mathrm{M})$ of labeled mannose-BSA in the presence or absence of the following compounds at $0^{\circ} \mathrm{C}$. Incubation time was the same as Table I. Binding was assayed as described in Methods and expressed as percent of the control values, which were $9.4,2.8,0.15$, and $0.41 \mathrm{ng}$ bound per well for alglucerase bound to COS cells and macrophages and mannose-BSA bound to COS cells and macrophages, respectively. Results are the mean of triplicate assays and representative of two independent experiments.

Table III. $\mathrm{Ca}^{2+}$ Dependency of Binding of Ligands

\begin{tabular}{|c|c|c|c|}
\hline & Mannan (-) & Mannan (+) & $\begin{array}{c}\text { Mannose- } \\
\text { dependent } \\
\text { binding }\end{array}$ \\
\hline & \multicolumn{3}{|c|}{ ng bound per well } \\
\hline \multicolumn{4}{|c|}{$\begin{array}{l}\text { Binding of mannose-BSA } \\
\text { to murine macrophages }\end{array}$} \\
\hline DTPA (-) & $0.48 \pm 0.04$ & $0.08 \pm 0.006$ & 0.4 \\
\hline DTPA (+) & $0.14 \pm 0.005$ & $0.12 \pm 0.04$ & 0.02 \\
\hline \multicolumn{4}{|c|}{$\begin{array}{l}\text { Binding of alglucerase } \\
\text { to Cos-1 cells }\end{array}$} \\
\hline DTPA (-) & $6.92 \pm 0.29$ & $0.94 \pm 0.05$ & 5.98 \\
\hline DTPA (+) & $6.84 \pm 0.19$ & $0.89 \pm 0.01$ & 5.95 \\
\hline \multicolumn{4}{|c|}{$\begin{array}{l}\text { Binding of alglucerase } \\
\text { to murine macrophages }\end{array}$} \\
\hline DTPA (-) & $3.45 \pm 0.13$ & $1.26 \pm 0.23$ & 2.19 \\
\hline DTPA (+) & $3.23 \pm 0.05$ & $1.02 \pm 0.06$ & 2.21 \\
\hline
\end{tabular}

Cos- 1 cells or murine peritoneal macrophages were incubated with 5 $\mu \mathrm{g} / \mathrm{ml}\left(8.4 \times 10^{-8} \mathrm{M}\right)$ of labeled alglucerase or $1 \mu \mathrm{g} / \mathrm{ml}\left(1.4 \times 10^{-8}\right.$ $\mathrm{M})$ of labeled mannose-BSA in the presence or absence of mannan and $4 \mathrm{mM}$ of DTPA at $0^{\circ} \mathrm{C}$. Incubation time was the same as Table I. During the incubation, DTPA did not affect adherence of both cell types. Results are the mean \pm SD of triplicate assays and are representative of two independent experiments.

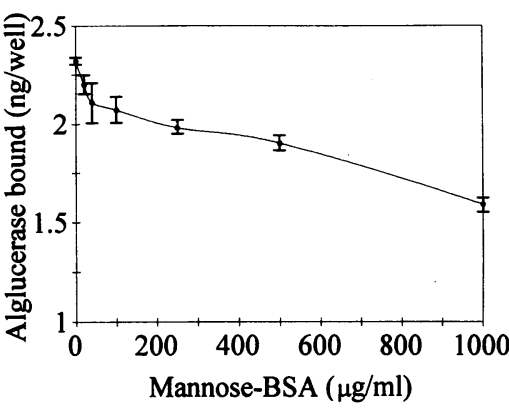

Figure 10. Inhibitory effect of mannose-BSA on binding of alglucerase to murine macrophages. Murine peritoneal macrophages were incubated with $2 \mu \mathrm{g} / \mathrm{ml}$ $\left(3.4 \times 10^{-8} \mathrm{M}\right)$ of labeled alglucerase in the presence or absence of various concentrations of unlabeled mannose-

BSA for $180 \mathrm{~min}$ at $0^{\circ} \mathrm{C}$. Binding was assayed as described in Methods. Results are the mean \pm SD of triplicate assays and are representative of two independent experiments.

we could not detect mannose-dependent binding of mannoseBSA (data not shown), considerable mannose-dependent binding of alglucerase was observed (Fig. $12 \mathrm{~A}$ ) and Scatchard analysis yielded a value of $1.1 \times 10^{6}$ receptors per cell, with a $K_{\mathrm{d}}$ of $2.7 \times 10^{-7} \mathrm{M}$ (Fig. $12 \mathrm{~B}$ ).

The mannose-dependent uptake was concentration dependent and from a double reciprocal plot the concentration giving one-half maximal uptake was determined to be $1.1 \times 10^{-6}$ M (Fig. 13).

\section{Discussion}

We found that murine peritoneal macrophages had $\sim 500,000$ mannose-dependent receptors for alglucerase per cell with a $K_{\mathrm{d}}$ of $1.2 \times 10^{-7} \mathrm{M}$. The number of binding sites is larger than has previously been described on rat alveolar macrophages by others using mannose-BSA (26), and the affinity of receptors for alglucerase is one order of magnitude lower than that for mannose-BSA. Using mannose-BSA in our system, we observed the same $K_{\mathrm{d}}$ in murine peritoneal macrophages $\left(10^{-8}\right.$ $M)$ as had been reported by others in alveolar macrophages but

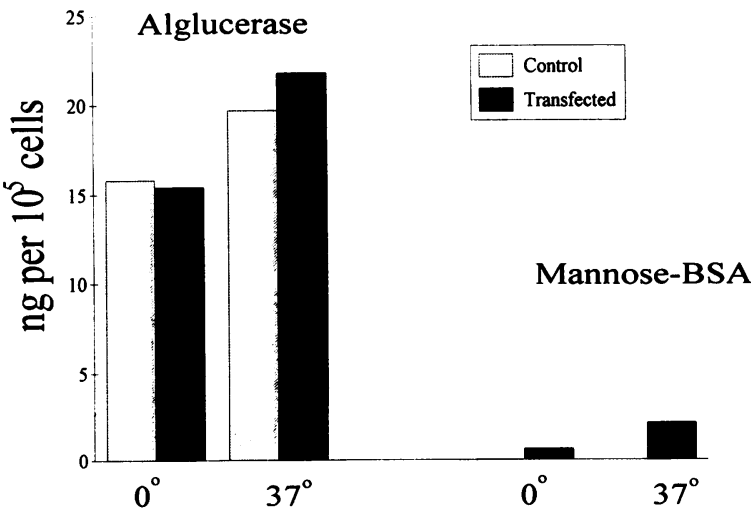

Figure 11. Binding and uptake of alglucerase and mannose-BSA by mannose receptor cDNA-transfected Cos-1 cells. Mannose receptor full-length cDNA-transfected Cos-1 cells and mock control cells were prepared as described in Methods. Both cells were incubated with 5 $\mu \mathrm{g} / \mathrm{ml}\left(8.4 \times 10^{-8} \mathrm{M}\right)$ of labeled alglucerase or $5 \mu \mathrm{g} / \mathrm{ml}\left(6.9 \times 10^{-8}\right.$ $M)$ of labeled mannose-BSA in the presence or absence of mannan for $180 \mathrm{~min}$ at $0^{\circ} \mathrm{C}$ or for $20 \mathrm{~min}$ at $37^{\circ} \mathrm{C}$. Mannose-dependent cellassociated radioactivity was measured as described in Methods. Results are the mean $\pm \mathrm{SD}$ of triplicate assays and are representative of three independent experiments. 

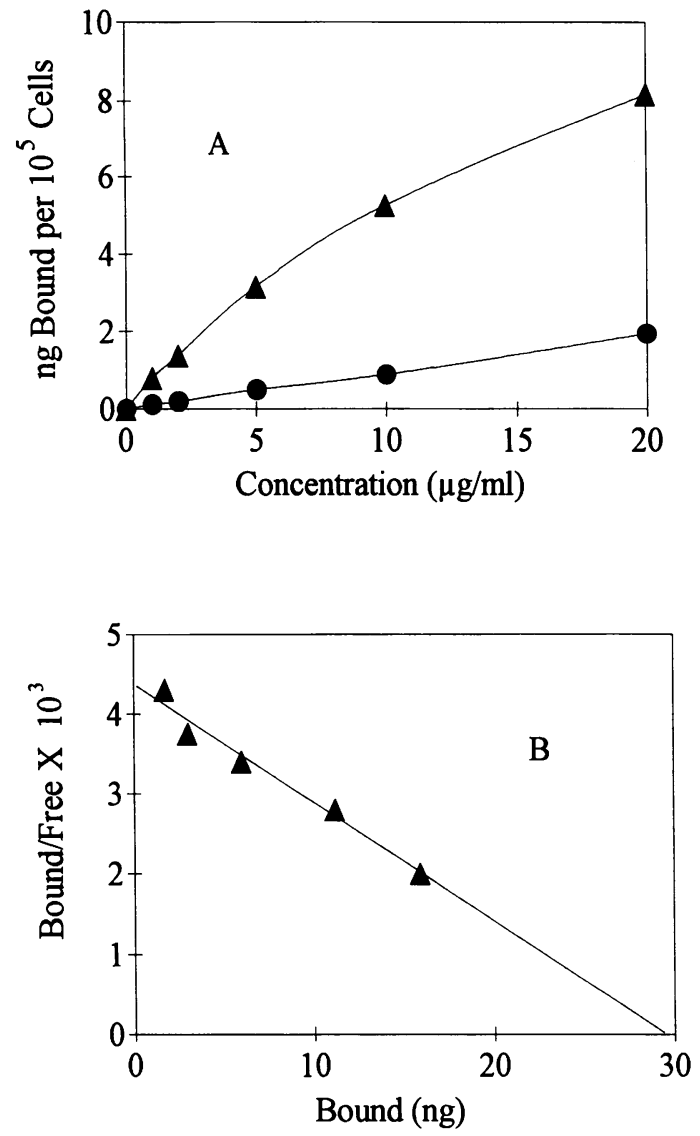

Figure 12. Binding of alglucerase to umbilical cord-derived endothelial cells as a function of concentration. $(A)$ Cells were incubated with various concentrations of labeled alglucerase in the presence or absence of mannan for $180 \mathrm{~min}$ at $0^{\circ} \mathrm{C}$. Binding was assayed as described in Methods. Results are the mean of duplicate assays and are representative of two independent experiments. $(B)$ Scatchard analysis of mannose-dependent binding.

observed a smaller number of binding sites $\left(2 \times 10^{4}\right.$ per cell $)$. Cell types or activation might reflect the difference in the number of binding sites. These findings suggested that alglucerase may be bound by a receptor that is distinct from the "classical" mannose receptor that binds mannose-BSA. Since the binding is not inhibited by mannose-6-phosphate or dextran sulfate (Table II), it is apparently not the mannose-6-phosphate receptor nor scavenger receptor.

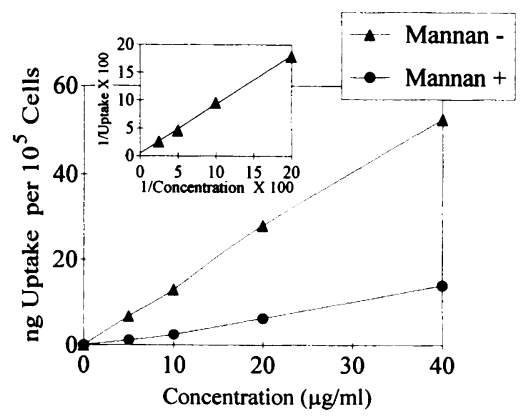

Figure 13. Uptake of alglucerase by umbilical cord-derived endothelial cells as a function of concentration. Cells were incubated with various concentrations of labeled alglucerase in the presence or absence of mannan for 60 min at $37^{\circ} \mathrm{C}$. Uptake was assayed as described in Methods. Results are the mean of duplicate assays and are representative of two independent experiments. (Inset) A double reciprocal plot of mannose-dependent uptake.
On the other hand, we found that monocytes and Cos-1 cells, which do not possess mannose receptors, bind and take up alglucerase in a mannose-dependent manner. In further investigations, we found that $\alpha$-methyl-glucoside is a potent inhibitor of alglucerase binding to Cos-1 cells but has relatively little effect on the binding of mannose-BSA to macrophages. Conversely, the binding of mannose-BSA to macrophages is inhibited by fucose but the binding of alglucerase to Cos- 1 cells is affected only a little by the latter sugar. In addition, alglucerase binding to Cos-1 cells is $\mathrm{Ca}^{2+}$ independent whereas binding of mannose-BSA to macrophages is $\mathrm{Ca}^{2+}$ dependent. To the best of our knowledge, this is the first evidence for the presence of such $\mathrm{Ca}^{2+}$-independent mannose binding site.

Using these parameters to differentiate two binding sites, we examined whether this $\mathrm{Ca}^{2+}$-independent site might be expressed on macrophages. Binding of alglucerase to macrophages was $\mathrm{Ca}^{2+}$ independent and was inhibited by $\alpha$-methylglucoside or fucose in the same manner as binding of alglucerase to Cos-1 cells. Taking into account the number of binding sites of mannose receptor $\left(2 \times 10^{4}\right.$ per macrophage $)$ and the $\mathrm{Ca}^{2+}$-independent receptor $\left(5 \times 10^{5}\right.$ per macrophage $)$ and the fact that mannose-BSA is an effective inhibitor for only $\sim 10 \%$ of the alglucerase binding on macrophages, this type of binding site apparently accounts for the major portion of alglucerase binding to macrophages and only a small portion of the enzyme is bound to the classical mannose receptor.

Because of the existence of two distinct binding sites, analysis of uptake of alglucerase by macrophages at $37^{\circ} \mathrm{C}$ is complicated. Mannose receptor cDNA-transfected Cos- 1 cells serve as a good model to investigate the mechanism of alglucerase uptake. As shown in Fig. 11, internalization of mannose-BSA via the classical mannose receptor seems to be much more effective than that of alglucerase via the $\mathrm{Ca}^{2+}$-independent receptor. A large intracellular mannose receptor pool and its rapid recycling might be responsible for this efficient internalization of mannose-BSA (7). Although there is no difference in binding of alglucerase between control and mannose receptor cDNA-transfected Cos-1 cells, there is apparently more uptake of alglucerase by latter cells. These data suggest that at $0^{\circ} \mathrm{C}$ alglucerase predominantly binds to the very numerous $\mathrm{Ca}^{2+}$-independent receptor, but that at $37^{\circ} \mathrm{C}$, a small number of efficient classical mannose receptors plays a major role in the internalization of alglucerase. It may well be that only the classical mannose receptor actually delivers its ligand to the lysozyme. About one half of the alglucerase that enters macrophages merely cycles through endocytic vacuoles or even dissociates from binding sites and does not remain in the lysosome. This could be the ligand bound by the $\mathrm{Ca}^{2+}$-independent receptor.

In Table IV, we summarize the characteristics of classical mannose receptor and $\mathrm{Ca}^{2+}$-independent receptor for alglucerase expressed on macrophages.

A large number of mannose-independent binding sites were also present on macrophages. In the case of murine, but not human, cells, a few of these were high affinity sites, which appear to be galactose receptors (27), but a much larger number, $10^{7}$ or greater, of low affinity sites were also found.

Our main purpose has been to evaluate the kinetics of alglucerase binding and uptake in human macrophages, but obtaining adequate numbers of purified macrophages from humans is difficult. Recently, it was reported that under appropriate culture conditions human peripheral blood monocytes mature 
Table IV. Summary of Characteristics of Two Receptors

\begin{tabular}{lcc}
\hline & $\begin{array}{c}\text { Classical } \\
\text { mannose } \\
\text { receptor }\end{array}$ & $\begin{array}{c}\mathrm{Ca}^{2+} \text {-independent } \\
\text { receptor }\end{array}$ \\
\hline Number of sites per macrophage & 20,000 & 500,000 \\
$K_{\mathrm{d}}(\mathrm{M})$ & $10^{-8}$ & $10^{-7}$ \\
Internalization & Efficient & $\begin{array}{c}\text { Poor } \\
\text { Inhibition by fucose (\%) }\end{array}$ \\
Inhibition by $\alpha$-methyl-glucoside (\%) & 0 & 9 \\
$\mathrm{Ca}^{2+}$ dependency & Dependent & Independent \\
\hline
\end{tabular}

into functionally differentiated macrophages, including mannose receptor expression $(25,28,29)$. The kinetics of the binding and uptake of labeled alglucerase by human monocytederived macrophages was found to be quite similar to the results obtained from murine peritoneal macrophages. However, the galactose receptor detected in murine macrophages was absent from the human cells, and the proportion of alglucerase taken up in a mannose-independent fashion was somewhat greater.

Our studies permit us to draw certain conclusions about the expected uptake of Ceredase ${ }^{\circledR}$ after infusion into human subjects. It has been reported that when alglucerase is administered in vivo at a rate of $0.13-0.45 \mathrm{U} / \mathrm{kg}$ per min, steady state levels of $1-5 \times 10^{-8} \mathrm{M}$ are achieved in the plasma (17). Our own report of similar levels at a lower infusion rate (15) was on the basis of a specific activity of $5.0 \mathrm{U} / \mathrm{mg}(18)$, a level that was erroneously low. The levels achieved at low dose therapy are $\sim 10^{-9} \mathrm{M}$ whereas high-dose therapy may provide levels of $10^{-8} \mathrm{M}$ or somewhat higher. At a concentration of alglucerase of $5 \times 10^{-8} \mathrm{M}$, achieved with high dose therapy, $80 \%$ or 16,000 of the 20,000 classical mannose receptor sites would be occupied whereas $24 \%$ or 120,000 of the $500,000 \mathrm{Ca}^{2+}$-independent sites would bind alglucerase. The ratio of alglucerase bound to the classical and presumably functional sites to that bound by the inefficient $\mathrm{Ca}^{2+}$-independent sites would be 1:7.5. In contrast, the concentration of $10^{-9} \mathrm{M}$ achieved by low dose, fractionated therapy would result in occupancy of $9 \%$ or 1,800 of the classical receptor sites and only $0.6 \%$ or 3,000 of the $\mathrm{Ca}^{2+}$-independent sites, or a ratio of $1: 1.7$. Thus the low concentration achieved by low dose therapy favors the classical receptor.

In our in vitro experiments at the high concentration, only $\sim 0.5 \%$ of the added alglucerase is taken up by macrophages. At an alglucerase concentration of $10^{-8} \mathrm{M}$, human monocytederived macrophages take up $1.6 \mathrm{ng}$ of alglucerase per $10^{5}$ cells (corresponding to $80 \mu \mathrm{U}$ per $10^{5}$ cells). As these cells normally contain $300 \mu \mathrm{U}$ per $10^{5}$ cells of endogenous catalytic activity, levels of only $27 \%$ of normal were achieved at this concentration. We also examined alglucerase uptake by monocyte-derived macrophages from a Gaucher patient. When incubated at a concentration of $10^{-7} \mathrm{M}$, which is one order of magnitude higher than the reported steady state plasma concentration when high dose therapy is given, cellular alglucerase activity of Gaucher disease patient monocyte-derived macrophages rose to $<50 \%$ of the activity found in normal macrophages. The amount of alglucerase taken up as measured by catalytic activ- ity was slightly less than that measured by radioactivity, which may be due to either the sensitivity of the assay or the stability of the alglucerase.

Although hepatic endothelial cells are reported to possess the same mannose receptor as expressed on macrophages (30, 31 ), umbilical cord-derived endothelial cells do not have mannose receptor (23). However, the presence of avid receptors for alglucerase on umbilical cord-derived endothelial cells suggests that much of the infused alglucerase may be taken up by endothelial cells. Preliminary studies of the bone marrow of patients immediately after infusion of Ceredase ${ }^{\otimes}$ is consistent with the conclusion that very little of the infused enzyme reaches macrophages. Very little of the alglucerase is found in marrow cells (our unpublished data).

We and others have clearly shown that treatment with alglucerase produces unmistakable objective improvement in patients with Gaucher disease, with marked decreases in the sizes of the spleen and liver in which glucocerebroside is stored (1214). The reason for the effectiveness of this preparation certainly is not due to efficient targeting to macrophages. It may be that the small amounts of alglucerase that do reach macrophages are sufficient to gradually reduce their burden of glucocerebroside. It is also conceivable that glucocerebroside hydrolysis occurs in unknown tissues. It is unlikely to occur in the plasma because the $\mathrm{pH}$ of the plasma is much higher than the $\mathrm{pH}$ optimum of glucocerebrosidase and because the essential co-factor, saposin, is not present ( unpublished data). Our studies lead us to suggest that an efficiently targeted enzyme might have a marked therapeutic advantage over alglucerase.

\section{Acknowledgments}

We are grateful for the helpful suggestions of Dr. Alan Ezekowitz and for his making available to us the mannose receptor cDNA clone.

Supported by National Institutes of Health grants DK-36639 and RR-00833 and the Sam Stein and Rose Stein Charitable Trust Fund. This is manuscript number 7429-MEM from The Scripps Research Institute.

\section{References}

1. Beutler, E. 1991. Gaucher's disease. N. Engl. J. Med. 325:1354-1360.

2. Brady, R. O., P. G. Pentchev, A. E. Gal, S. R. Hibbert, and A. S. Dekaban 1974. Replacement therapy for inherited enzyme deficiency. Use of purified glucocerebrosidase in Gaucher's disease. N. Engl. J. Med. 291:989-993.

3. Brady, R. O., A. E. Gal, and P. G. Pentchev. 1974. Evolution of enzyme replacement therapy for lipid storage diseases. Life Sci. 7:1235-1248.

4. Beutler, E., and G. L. Dale. 1979. Enzyme replacement therapy. In Covalent and Non-covalent Modulation of Protein Function. D. Atkinson and C. F. Fox, editors. Academic Press, Inc., New York. 449-461.

5. Beutler, E., G. L. Dale, E. Guinto, and W. Kuhl. 1977. Enzyme replacement therapy in Gaucher's disease: preliminary clinical trial of a new enzyme preparation. Proc. Natl. Acad. Sci. USA. 74:4620-4623.

6. Belchetz, P. E., J. C. W. Crawley, I. P. Braidman, and G. Gregoriadis. 1977. Treatment of Gaucher's disease with liposome-entrapped glucocerebroside:betaglucosidase. Lancet 2:116-117.

7. Ezekowitz, R. A. B., and P. D. Stahl. 1988. The structure and function of vertebrate mannose lectin-like proteins. J. Cell Sci. 9:121-133.

8. Achord, D. T., F. E. Brot, C. E. Bell, and W. S. Sly. 1978. Human beta-glucuronidase: in vivo clearance and in vitro uptake by a glycoprotein recognition system on reticuloendothelial cells. Cell. 15:269-278.

9. Pentchev, P. G., A. E. Barranger, A. E. Gal, F. S. Furbish, and R. O. Brady. 1978. Incorporation of exogenous enzymes into lysosomes. A theoretical and practical means for correcting lysosomal blockage. In Glycoproteins and Glycolipids in Disease Processes. E. F. Walborg, Jr., editor. ACS Symposium Series, American Chemical Society, Washington, DC. 150-159.

10. Takasaki, S., G. J. Murray, F. S. Furbish, R. O. Brady, J. A. Barranger, and 
A. Kobata. 1984. Structure of the $\mathrm{N}$-asparagine-linked oligosaccharide units of human placental $\beta$-glucocerebrosidase. J. Biol. Chem. 259:10112-10117.

11. Murray, G. J. 1987. Lectin-specific targeting of lysosomal enzymes to reticuloendothelial cells. Methods Enzymol. 149:25-42.

12. Barton, N. W., R. O. Brady, J. M. Dambrosia, A. M. Di Bisceglie, S. H Doppelt, S. C. Hill, H. J. Mankin, G. J. Murray, R. I. Parker, C. E. Argoff, et al. 1991. Replacement therapy for inherited enzyme deficiency-macrophage-targeted glucocerebrosidase for Gaucher's disease. $N$. Engl. J. Med. 324:1464-1470.

13. Beutler, E., A. Kay, A. Saven, P. Garver, D. Thurston, A. Dawson, and B. Rosenbloom. 1991. Enzyme replacement therapy for Gaucher disease. Blood. 78:1183-1189.

14. Fallet, S., A. Sibille, R. Mendelson, D. Shapiro, G. Hermann, and G. A. Grabowski. 1992. Enzyme augmentation in moderate to life-threatening Gaucher disease. Pediatr. Res. 31:496-502.

15. Beutler, E., A. C. Kay, A. Saven, P. Garver, and D. W. Thurston. 1991. Enzyme replacement for Gaucher's disease. N. Engl. J. Med. 325:1809-1810.

16. Zimran, A., I. Hadas-Halpern, and A. Abrahamov. 1991. Enzyme replacement therapy for Gaucher's disease. N. Engl. J. Med. 325:1810-1811.

17. Barton, N. W., R. O. Brady, G. J. Murray, C. E. Argoff, R. P. Grewal K.-T. Yu, J. M. Dambrosia, A. M. DiBisceglie, S. C. Hill, R. I. Parker, et al. 1991. Enzyme-replacement therapy for Gaucher's disease: reply. N. Engl. J. Med. 325:1811.

18. Dale, G. L., and E. Beutler. 1976. Enzyme replacement therapy in Gaucher's disease: a rapid high-yield method for purification of glucocerebrosidase. Proc. Natl. Acad. Sci. USA. 73:4672-4674.

19. Lowry, O. H., N. J. Rosebrough, A. L. Farr, and R. J. Randall. 1951. Protein measurement with the Folin phenol reagent. J. Biol. Chem. 193:265275.

20. Freundlich, B., and N. Avdalovic. 1983. Use of gelatin/plasma coated flasks for isolating human peripheral blood monocytes. J. Immunol. Methods. 62:31-37.

21. Konish, M., V. Shepherd, G. Holt, and P. Stahl. 1983. Uptake of glycoproteins and glycoconjugates by macrophages. Methods Enzymol. 98:301-304.
22. Stanley, E. R. 1985. The macrophage colony-stimulating factor, CSF-1. Methods Enzymol. 116:564-587.

23. Ezekowitz, R. A. B., K. Sastry, P. Bailly, and A. Warner. 1990. Molecular characterization of the human macrophage mannose receptor. Demonstration of multiple carbohydrate recognition-like domains and phagocytosis of yeasts in Cos-1 cells. J. Exp. Med. 172:1785-1794.

24. Raghavan, S. S., J. Topol, and E. H. Kolodny. 1980. Leukocyte beta-glucosidase in homozygotes and heterozygotes for Gaucher disease. Am. J. Hum. Genet. 32:158-173.

25. Shepherd, V. L., E. J. Campbell, R. M. Senior, and P. D. Stahl. 1982. Characterization of the mannose / fucose receptor on human mononuclear phagocytes. J. Reticuloendothel. Soc. 32:423-431.

26. Stahl, P., P. H. Schlesinger, E. Sigardson, J. S. Rodman, and Y. C. Lee. 1980. Receptor-mediated pinocytosis of mannose glycoconjugates by macrophages: characterization and evidence for receptor recycling. Cell. 19:207-215.

27. Roos, P. H., H.-J. Hartman, J. Schlepper-Schäfer, H. Kolb, and V. KolbBachofen. 1985. Galactose-specific receptors on liver cells. II. Characterization of the purified receptor from macrophages reveals no structural relationship to the hepatocyte receptor. Biochim. Biophys. Acta. 847:115-121.

28. Musson, R. A. 1983. Human serum induces maturation of human monocytes in vitro. Changes in cytolytic activity, intracellular lysosomal enzymes, and nonspecific esterase activity. Am. J. Pathol. 111:331-340.

29. Andreesen, R., W. Brugger, C. Scheibenbogen, M. Kreutz, H.-G. Leser, A Rehm, and G. W. Löhr. 1990. Surface phenotype analysis of human monocyte to macrophage maturation. J. Leukocyte Biol. 47:490-497.

30. Magnusson, S., and T. Berg. 1989. Extremely rapid endocytosis mediated by the mannose receptor of sinusoidal endothelial rat liver cells. Biochem. J. 257:651-656.

31. Kindberg, G. M., S. Magnusson, T. Berg, and B. Smedsrod. 1990. Receptor-mediated endocytosis of ovalbumin by two carbohydrate-specific receptors in rat liver cells. Biochem. J. 270:197-203. 